\title{
SROVNÁVACÍ STUDIE POVRCHU KŘEMENNÝCH ZRN NA LOKALITÁCH JIŽNÍ A JIHOVÝCHODNÍ MORAVY
}

\author{
The comparative study of the surface of the quartz grains at the south and southeast \\ Moravia sites \\ Jana Šušolová1,4, Veronika Králová2 ${ }^{2}$, Roman Hadacz ${ }^{3}$, Peter Dundek ${ }^{4}$, Daniel Volařík ${ }^{4}$ \\ ${ }^{1}$ Moravské zemské muzeum, Zelný trh 6, 65937 Brno; e-mail:jsusolova@mzm.cz \\ ${ }^{2}$ TESCAN, Libušina tř. 21, 62300 Brno-Kohoutovice; e-mail:veronika.kralova@gmail.com \\ ${ }^{3}$ Garmur.cz, s.r. o., Nebovidy 497, 66448 Brno-venkov; e-mail: roman.hadacz@gmail.com \\ ${ }^{4}$ Mendelova univerzita v Brně, Zemědělská 3, 61300 Brno; e-mail:peter.dundek@gmail.com; daniel.volarik@seznam.cz
}

(34-24 Holíč, 34-22 Hodonín, 24-42 Kojetín, 25-33 Uherské Hradiště, 34-11 Znojmo)

Key words: Mikulčice, Eolian Sediments, Fluvial Sediments, Exoscopy, SEM, NMDS

\begin{abstract}
Between 2013-2014, archeological researches at the Mikulčice site were performed. During these researches, necessity of a quartz grains surface study in the Moravian Sahara arose. There is a significant archaeological monument situated near the village of Mikulčice - a Slavic settlement, whose youngest bedrock is formed by fluvial sediments of extinct riverarms of the river Morava, and sand dunes composed of wind-blown sands of the Moravian Sahara. On these sand dunes, the most important churches and palaces of the settlement are found. The sandy sediments can reach up to $30 \mathrm{~m}$ thickness in the area of the Moravian Sahara.

Samples of sandy sediments were taken from several locations of this site, and also from several other sites of south Moravia, which are sedimentary genetically different from the studied area. One sample of aeolian sand from the desert Rub-al Khali of Arabian Peninsula was provided for comparison.

After gathering this small collection of sand grain samples, they were individually modified to the required study form and analyzed according to the demands of the method of exoscopy. At first, one hundred quartzgrains were separated from each sample of the collection using a stereo microscope. After that a detailed study and imaging with the scanning electronmicroscope (SEM) followed. The collection of sands from Mikulčice of the same genetical origin was compared to other samples of genetically known origin (fluvial, eolian...). The final comparison of all samples was performed by the method of multivariate analysis with NMDS. The results show that development of sediments at the archeological site Mikulčice most probably took place in very similar sedimentary environment. In this environment, the eolian transport and the fluvial transport with lower kinetic energy played important role.
\end{abstract}

Úvod

Slovanské Hradisko Mikulčice, vzdálené asi $3 \mathrm{~km}$ jv. od obce Mikulčice, je situované v údolní nivě řeky Moravy. Jeho nejvýznamnější kostely a paláce jsou lokalizovány na čtyřech dunách navátých písků. Významným morfologickým prvkem zde jsou říční ramena, která původně obtékala jednotlivé duny a další vyvýšeniny a oddělovala je od sebe. Hlavními zájmy studie bylo přiblízit genezi transportu písčitých zrn do této oblasti a porovnat mezi sebou jednotlivé vzorky $\mathrm{z}$ hlediska podobnosti. Pro tato zjištění byla zvolena metoda exoskopie a následně NMDS. Ke srovnání se vzorky z Mikulčic bylo vybráno několik lokalit převážně z Moravy a jedna $\mathrm{z}$ Arabského poloostrova. U vybraných lokalit, kde se předpokládal jasný geneticky sedimentární původ, se dalším pozorováním zjistilo, že tomu tak není (viz dále). Jedinou lokalitou s geneticky zřetelným sedimentárním původem je písčitá duna z Arabského poloostrova.

\section{Geologie}

Širši okolí Mikulčic náleží z hlediska orografického členění Dolnomoravskému úvalu. Geologicky jde o neogenní vídeňskou pánev, vyplněnou 5000 až 5500 m mocnými nepravidelně se střídajícími polohami miocenních jílů, prachů, písků a štěrků s nepravidelnými vrstvami řasových vápencủ. Ve svrchním miocénu se $\mathrm{v}$ této oblasti rozšírily plošně rozsáhlé bažiny, ve kterých se nahromadila uhelná hmota tvořící lignitové sloje. Koncem neogénu, v pontu až pliocénu, se začaly ukládat jezerní, rriční a další kontinentální sedimenty. V kvartérní historii se v okolí uložily fluviální písky, písčité štěrky a naváté písky (Chlupáč et al. 2002; Havlíček 2006; Havlíček - Peška 1992).

Ve viselském glaciálu byly z miocenních mořských sedimentů a kvartérních teras řeky Moravy vyváty jejich jemnější části a vznikla rozsáhlá oblast vátých písků, tzv. Moravská Sahara, na ploše cca 95 ha. Mocnost převládajících, dobře vytříděných písčitých uloženin akumulovaných západními a severozápadními větry se pohybuje v rozmezí mezi 2 až $20 \mathrm{~m}$, výjimečně dosahuje až $30 \mathrm{~m}$ (Havlíček - Zeman 1986).

\section{Metodika}

Metodika exoskopie, použitá v tomto výzkumu, byla převzata z publikace Kř́žová et al. (2011). Byly odebrány vzorky o hmotnosti $0,5 \mathrm{~kg}$, které byly dále pomocí sít zrnitostně vytř́děny i na velikost $0,50-0,25 \mathrm{~mm}$. Pro exoskopická pozorování je doporučena velikost zrn 200 až $500 \mu$ (Kř́žová et al. 2011). Sledovaná zrnitostní frakce byla povařena s koncentrovanou $\mathrm{HCl}$ pro odstranění nežádoucích karbonátů, jílů a organických materiálů. Dále byly vzorky propláchnuty, zneutralizovány destilovanou vodou a vysušeny. Tyto laboratorní práce byly provedeny na Ústavu geologie a pedologie Mendelovy univerzity v Brně. 
Po důkladném makroskopickém studiu zrn pod stereomikroskopem OPTIKA LAB-2 bylo vyseparováno z každého vzorku 100 křemenných zrn, aby byl k dispozici dostatečně velký, statisticky hodnotitelný soubor dat pro studii povrchových tvarů, jejich četnosti a zastoupení na jednotlivých zrnech. Pro detailní analýzu zrn byl vybrán autoemisní elektronový mikroskop MIRA3 od firmy TESCAN, a. s., vybavený detektorem sekundárních elektronů typu Everhart-Thornley a energiově disperzním spektrometrem. Zrna byla na držák fixována pomocí uhlíkové pásky. Aby se předešlo nabíjení vzorku, na povrch zrn byla nanesena vrstva uhlíku o tlouštce $15 \mathrm{~nm}$. Byly pořízeny detailní snímky zrn.

Dalším sledovaným texturním znakem klastických sedimentů byl stupeň zaoblení klastických částic. K odhadu zaoblení se použila vizuální škála uvedená v Návodu pro pojmenování a popis zemin (ČSN 72 1001, ČSN 73 1001).

Barva sedimentů jednotlivých frakcí se zjištovala za sucha pomocí Munsellových tabulek barevnosti půd (MunsellColor 2000).

Pro statistické zpracování vzorků byla zvolena jako nejvhodnější metoda mnohorozměrné analýzy NMDS využívající euklidovských vzdáleností, kdy poloha znaků vyjadřuje polohu vektorů př́slušných znaků. Díky této metodě zjistíme míru shody vzdáleností na ordinačním diagramu a původní hodnoty nepodobnosti jednotlivých vzorků.
-Hradisko. Odběr byl proveden na valu vedle kostela, v hloubce $230-290 \mathrm{~cm}$.

- Vzorek M4 byl odebírán z předpokládané přeplavené duny, Mikulčice-Hradisko. Odběr byl proveden ze svahu vedle kostela, v hloubce $280-320 \mathrm{~cm}$.

- Vzorek M5 byl odebírán z předpokládané duny na louce pod valem, Mikulčice-Hradisko, v hloubce $100-200 \mathrm{~cm}$.

- Vzorek M7 byl odebírán jako předpokládaný ŕíční písek v sondě, Mikulčice-Hradisko, z hloubky cca $100 \mathrm{~cm}$.

- Vzorek M8 byl odebírán na lokalitě Osypané břehy nedaleko Strážnice $\mathrm{z}$ hloubky $2 \mathrm{~m}$ pod povrchem z odkrytého profilu s eolickými, eolickofluviálními a lakustrinními sedimenty.

- Vzorek M9 byl odebírán na lokalitě Osypané břehy nedaleko Strážnice z hloubky $8 \mathrm{~m}$ pod povrchem z odkrytého profilu s eolickými, eolickofluviálními a lakustrinními sedimenty.

- Vzorek M10 byl odebírán z pískovny mezi obcemi Litenčice a Nítkovice. Jedná se o terciérní mořské sedimenty karpatu.

- Vzorek M11 byl odebrán ze sedimentů středního toku řeky Olšavy. Řeka v místě odběru protéká sprašovými sedimenty.

- Vzorek M12 byl odebrán z břehu řeky Moravy (střední tok) nedaleko Mikulčic.

- Vzorek M13 byl odebrán ze středního toku řeky Jevišovky v obci Plaveč.

\section{Lokalizace odběrů}

Pro exoskopické analýzy bylo odebráno 14 vzorků psamitů $\mathrm{z}$ několika lokalit (obr. 1). Vzorky M0-M7 byly odebrány z oblasti Mikulčice-Trapíkov a Mikulčice-Hradisko a vzorky M8-M14 z různých sedimentárně genetických lokalit:

- Vzorek M0 byl odebírán z předpokládané duny v době výzkumu v Trapíkově před postavením centra Archeologického ústavu AV ČR. Hloubka odběru byla $50 \mathrm{~cm}$.

- Vzorek M1 byl odebírán z předpokládané duny. Odběr byl proveden u silnice mezi stromy před novým centrem Archeologického ústavu AV ČR, oblast Trapíkova. Hloubka odběru byla $50 \mathrm{~cm}$.

- Vzorek M2 byl odebírán z předpokládané duny, Mikulčice-Hradisko. Odběr byl proveden u chodníku pro návštěvníky areálu. Hloubka odběru byla $50 \mathrm{~cm}$, kde se již objevil písek, nad ním se vyskytuje jílovitější tužší sediment (hodnoceno za mokra).

- Vzorek M3 byl odebírán z předpokládané duny, Mikulčice-

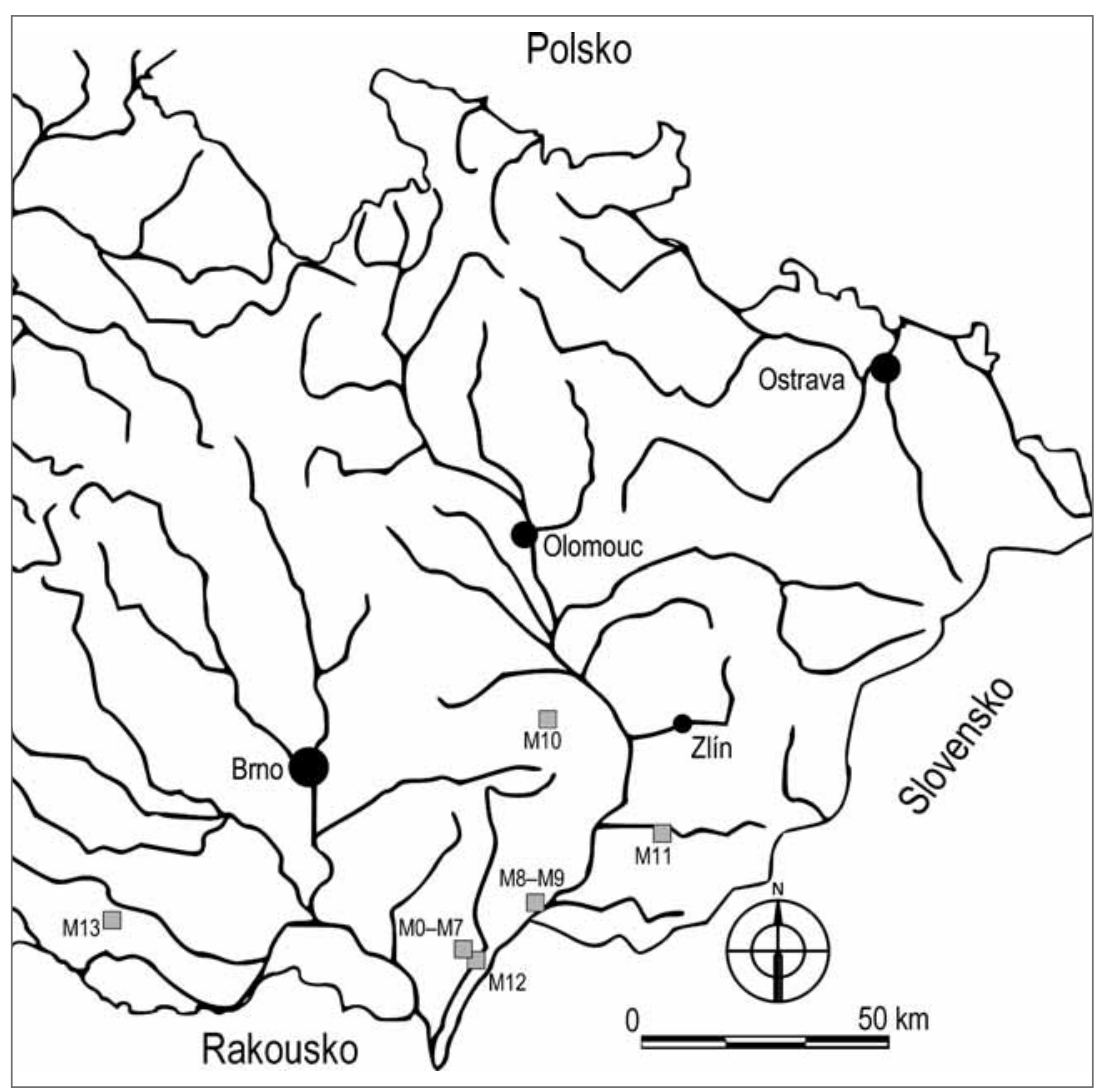

Obr. 1: Mapa s vyznačeným odběrem vzorků (upraveno podle http://www.zemepis-vorlicek.estranky.cz/file/39/cr-vodstvo.jpg)

Fig. 1: The map showing the sampling (adapted from http://www.zemepis-vorlicek. estranky.cz/file/39/cr-vodstvo.jpg). 
- Vzorek M14 byl odebrán z duny na poušti Rub' al-Khali, patř́cí do Spojených arabských emirátů, mezi městy Dubai a Al Ain.

Tab. 1: Zrnitost a barva odebraných vzorků (dle Munsellových tabulek barevnosti půd 2000).

Tab. 1: The granularity and colour of the samples (according to Munsell Soil Color Charts 2000).

\begin{tabular}{|l|c|c|c|c|}
\hline č. vzorku & $\begin{array}{c}<0,004 \\
{[\mathrm{~mm}]}\end{array}$ & $\begin{array}{c}0,004-0,063 \\
{[\mathrm{~mm}]}\end{array}$ & $\begin{array}{c}0,063-2,000 \\
{[\mathrm{~mm}]}\end{array}$ & barva \\
\hline M0 & 4,1 & 3,6 & 92,3 & 10 YR 6/4 \\
\hline M1 & 3,4 & 3,7 & 92,9 & 10 YR 5/3 \\
\hline M2 & 4,6 & 8,0 & 87,4 & 10 YR 5/4 \\
\hline M3 & 3,1 & 4,4 & 92,4 & 10 YR 5/4 \\
\hline M4 & 6,6 & 5,7 & 87,7 & 10 YR 5/4 \\
\hline M5 & 4,1 & 4,2 & 91,7 & 10 YR 5/4 \\
\hline M7 & 1,2 & 0,5 & 98,3 & 10 YR 6/3 \\
\hline M8 & 5,2 & 1,8 & 93,0 & 10 YR 6/4 \\
\hline M9 & 5,5 & 0,9 & 93,6 & 10 YR 6/4 \\
\hline M10 & 5,8 & 7,6 & 86,6 & 2,5 Y 6/4 \\
\hline M11 & 6,0 & 10,2 & 83,8 & 2,5 Y 5/3 \\
\hline M12 & 11,8 & 37,7 & 50,5 & 2,5 Y 5/3 \\
\hline M13 & 6,6 & 10,5 & 82,9 & 10 YR 5/3 \\
\hline M14 & 0,2 & 0,5 & 99,3 & 10 YR 8/1 \\
\hline
\end{tabular}

\section{Výsledky pozorování}

Odebrali jsme vzorky písků z předpokládaných geneticky odlišných prostředí lokalit Trapíkov a Hradisko v Mikulčicích. Některé vzorky byly z místa duny (M0, M1, M2, M3, M5), tedy eolické sedimenty. Další byly z místa, kde je přeplavená duna (M4) a jeden vzorek (M7) přímo $\mathrm{z}$ místa, kde v minulosti řeka obtékala dunu, tedy teoreticky fluviální sediment.

Barva sedimentů byla určena za sucha podle Munsellových tabulek barevnosti půd (tab. 1). Odstíny se pohybují od žlutohnědých po hnědé. Z hlediska barevnosti zrn se vyskytovala zrna čirá, mléčně bílá, nažloutlá a narezivělá u všech vzorků. Zrnitost byla provedena pomocí sítování a pipetovací metodou z navážky $20 \mathrm{~g}$ podle Jandák et al. (2009). U vzorků převažuje písčitá frakce s jemnou příměsí prachu a jílu (tab. 1).

U vzorků bylo sledováno 28 vlastností (tab. 2), $\mathrm{z}$ nichž byl dále proveden kvantitativní součet.

Ordinační diagram znázorňuje zkoumané vzorky (M0-M14) promítnuté do dvourozměrného prostoru na základě podobnosti/nepodobnosti četnosti výskytu jednotlivých typů mikrotextur (obr. 2). Vzorky podobné z hlediska četnosti výskytu jednotlivých mikrotextur leží v grafu blízko sebe, nepodobné naopak daleko od sebe (obr. 3). Ukázky mikrotextur jsou zachyceny na obrázcích 4,5 a 6.

Tab. 2: Četnost mikrotextur u jednotlivých vzorků.

Tab. 2: The frequencies of microtextures of samples.

\begin{tabular}{|c|c|c|c|c|c|c|c|c|c|c|c|c|c|c|}
\hline & M0 & M1 & M2 & M3 & M4 & M5 & M7 & M8 & M9 & M10 & M11 & M12 & M13 & M14 \\
\hline ostrohranné & 15 & 4 & 2 & 1 & 1 & 1 & 5 & 1 & 0 & 58 & 23 & 13 & 34 & 0 \\
\hline polostrohranné & 33 & 26 & 19 & 15 & 26 & 17 & 19 & 10 & 11 & 26 & 38 & 27 & 50 & 4 \\
\hline polooválné & 30 & 30 & 35 & 47 & 36 & 36 & 30 & 49 & 44 & 14 & 26 & 31 & 15 & 30 \\
\hline oválné & 22 & 36 & 41 & 37 & 35 & 46 & 46 & 40 & 45 & 2 & 13 & 29 & 1 & 52 \\
\hline dokonale oválné & 0 & 4 & 3 & 0 & 2 & 0 & 0 & 0 & 0 & 0 & 0 & 0 & 0 & 14 \\
\hline nízký reliéf & 25 & 28 & 45 & 53 & 67 & 74 & 68 & 55 & 57 & 5 & 20 & 40 & 9 & 77 \\
\hline střední reliéf & 54 & 43 & 38 & 41 & 29 & 24 & 31 & 44 & 43 & 41 & 67 & 55 & 73 & 23 \\
\hline vysoký reliéf & 21 & 28 & 17 & 6 & 4 & 2 & 1 & 1 & 0 & 54 & 12 & 5 & 18 & 0 \\
\hline lasturnatý lom & 10 & 14 & 12 & 18 & 25 & 23 & 30 & 3 & 5 & 25 & 19 & 12 & 23 & 16 \\
\hline rovné stupně & 36 & 25 & 24 & 19 & 24 & 24 & 36 & 14 & 10 & 46 & 42 & 23 & 58 & 18 \\
\hline obloukové stupně & 65 & 35 & 35 & 13 & 37 & 43 & 45 & 49 & 59 & 69 & 64 & 48 & 68 & 37 \\
\hline abraze hran & 34 & 37 & 27 & 26 & 17 & 16 & 18 & 4 & 2 & 30 & 30 & 15 & 37 & 2 \\
\hline$V-$ jamky & 44 & 61 & 65 & 81 & 62 & 70 & 72 & 58 & 44 & 26 & 35 & 46 & 24 & 96 \\
\hline mísovité jamky & 31 & 62 & 62 & 33 & 42 & 35 & 34 & 47 & 30 & 5 & 14 & 25 & 16 & 45 \\
\hline srpkovité tvary & 1 & 8 & 5 & 12 & 0 & 8 & 7 & 0 & 0 & 0 & 0 & 0 & 1 & 21 \\
\hline klikaté hřbítky & 52 & 24 & 36 & 53 & 56 & 45 & 37 & 43 & 26 & 35 & 42 & 69 & 58 & 4 \\
\hline paralelní rýhy & 3 & 2 & 2 & 7 & 4 & 1 & 4 & 0 & 0 & 0 & 0 & 0 & 3 & 6 \\
\hline rovné brázdy & 42 & 62 & 44 & 49 & 55 & 60 & 57 & 48 & 46 & 8 & 32 & 23 & 24 & 41 \\
\hline obloukové brázdy & 1 & 13 & 5 & 4 & 6 & 13 & 7 & 3 & 7 & 6 & 2 & 3 & 4 & 1 \\
\hline štěpné plátky & 20 & 3 & 5 & 1 & 1 & 0 & 0 & 0 & 1 & 1 & 1 & 1 & 2 & 7 \\
\hline tečkování & 27 & 41 & 50 & 66 & 64 & 78 & 78 & 78 & 89 & 29 & 41 & 44 & 12 & 97 \\
\hline orientované vyleptané jamky & 12 & 2 & 2 & 1 & 3 & 2 & 1 & 0 & 1 & 1 & 2 & 0 & 0 & 0 \\
\hline nárůsty krystalů & 0 & 4 & 17 & 19 & 7 & 1 & 0 & 0 & 0 & 0 & 0 & 0 & 0 & 0 \\
\hline přilnavé částice & 81 & 68 & 63 & 58 & 34 & 59 & 34 & 80 & 73 & 72 & 79 & 95 & 97 & 37 \\
\hline křemičité globule & 76 & 35 & 68 & 55 & 32 & 22 & 11 & 76 & 93 & 78 & 84 & 99 & 98 & 4 \\
\hline křemičité skrývky & 30 & 80 & 78 & 62 & 94 & 90 & 69 & 54 & 37 & 39 & 61 & 81 & 64 & 12 \\
\hline křemičité povlaky & 34 & 25 & 19 & 10 & 26 & 59 & 76 & 2 & 0 & 0 & 10 & 1 & 1 & 18 \\
\hline puklinové plochy & 28 & 12 & 7 & 4 & 10 & 18 & 14 & 4 & 4 & 20 & 12 & 13 & 5 & 2 \\
\hline
\end{tabular}


Srovnáme-li jednotlivé vzorky M0M7 mezi sebou (obr. 3 a tab. 2), zjistíme, že u všech je minimální zastoupení ostrohranných a dokonale oválných zrn, která u některých vzorků i zcela chybí. Nejvíce ostrohranných zrn má vzorek M0 (obr. 7A, B). U všech vzorků je největší zastoupení oválných a polooválných zrn. U většiny vzorků převládá nízký a střední reliéf. Vzorky M0 a M1 mají nejméně zrn s nízkým reliéfem a nejvyšší počet zrn s vysokým reliéfem. Největší množství zrn s nízkým reliéfem má vzorek M5 a M7 (obr. 8B, C, D), které mají zároveň i nejméně zrn s vysokým reliéfem a největší množství oválných zrn. Nejvíce zastoupenými mikrotexturami jsou křemičité skrývky, V - jamky a tečkování. Mezi dalšími mikrotexturami převládají rovné brázdy, přilnavé částice, mísovité jamky, klikaté hřbítky, křemičité globule a povlaky a obloukové stupně. Celkově je u všech vzorků velké zastoupení nárůstových křemičitých mikrotextur. Nejmenší je výskyt štěpných plátků, orientovaných vyleptaných jamek, paralelních rýh a srpkovitých tvarů.

Z hlediska četnosti jednotlivých mikrotextur jsou si velmi podobné vzorky M5 a M7. Vzorky M4, M5 a M7 mají velmi shodné zastoupení nejčetnějších mikrotextur (nízký reliéf, V - jamky, klikaté hřbítky, rovné brázdy, tečkování, přilnavé částice, křemičité skrývky). Podle Euklidovských vzdáleností je vzorek M0 nejpodobnější vzorku M2, vzorek M1 vzorku M2, vzorek M3 vzorku M2, vzorek M4 vzorku M5, vzorek M5 vzorkům M7 a M4 a vzorek M7 je nejpodobnější vzorku M5. Naopak nejvíce se od sebe odlišuje vzorek M0 a vzorek M7.

Vzorky M8 a M9 byly odebrány ze stejného profilu, z různých hloubek, mají podobné zastoupení převládajících mikrotextur i těch s téměř nulovým výskytem.

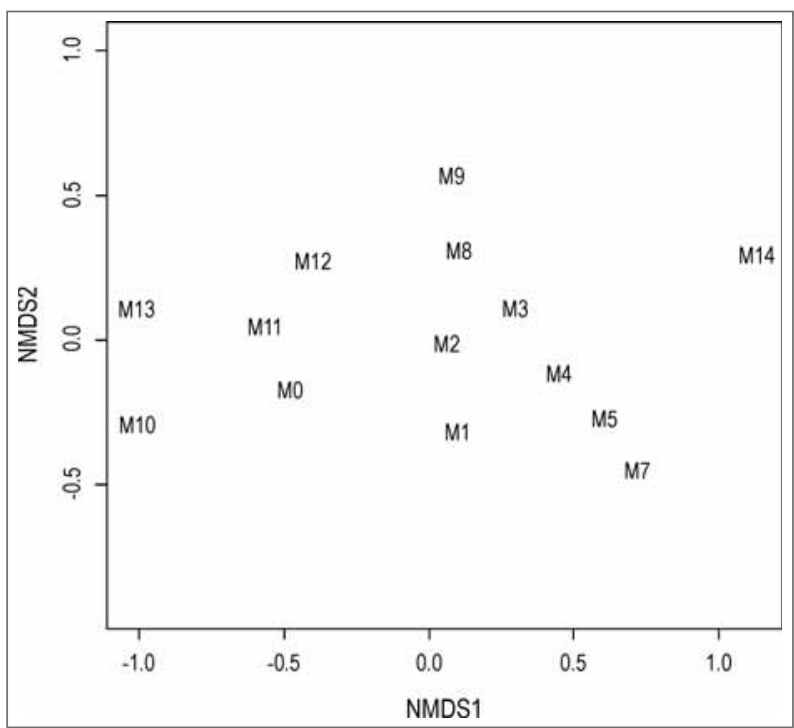

Obr. 2: Ordinační diagram vytvořený metodou NMDS na základě euklidovských vzdáleností vzorků mezi sebou (viz tab. 3).

Fig. 2: Ordination diagram of NMDS analysis based on the Euclidean distance among individual samples (see Tab. 3).
Z hlediska Euklidovských vzdáleností jsou si velmi blízké. Vzorek M8 (obr. 8E) je trochu více podobný vzorkům z lokality Mikulčice, než vzorek M9. Oba tyto vzorky, M8 i M9, jsou však více podobné vzorkům M0-M7 než zbývající vzorky M10-M14. Vzorek M10 je charakterem svých mikrotextur nejvíce podobný vzorku M11, M13 a M0, nejméně je podobný vzorku M14. Vzorku M11 je velmi podobný vzorek M13, M0 a M12 a nejvíce od něj odlišný je M14 a M7.

Vzorek M12 je nejblíže podobný vzorku M11 a nejvzdálenější je vzorku M14 (obr. 9). Vzorek M13 je nejblíže podobný vzorku M11 a nejvzdálenější vzorku M14. Vzorek M14 má největší zastoupení dokonale oválných zrn. Nejvíce je podobný vzorku M7, nejméně pak vzorku M13.

Pozorováním pod stereomikroskopem jsme zjistili, že téměř u všech těchto vzorků se na zrnech vyskytují povlaky rezivé barvy. Tyto byly podrobněji zkoumány pod elektronovým mikroskopem. Pomocí detektoru firmy Bruker byla vykreslena mapa prvků těchto povlaků.

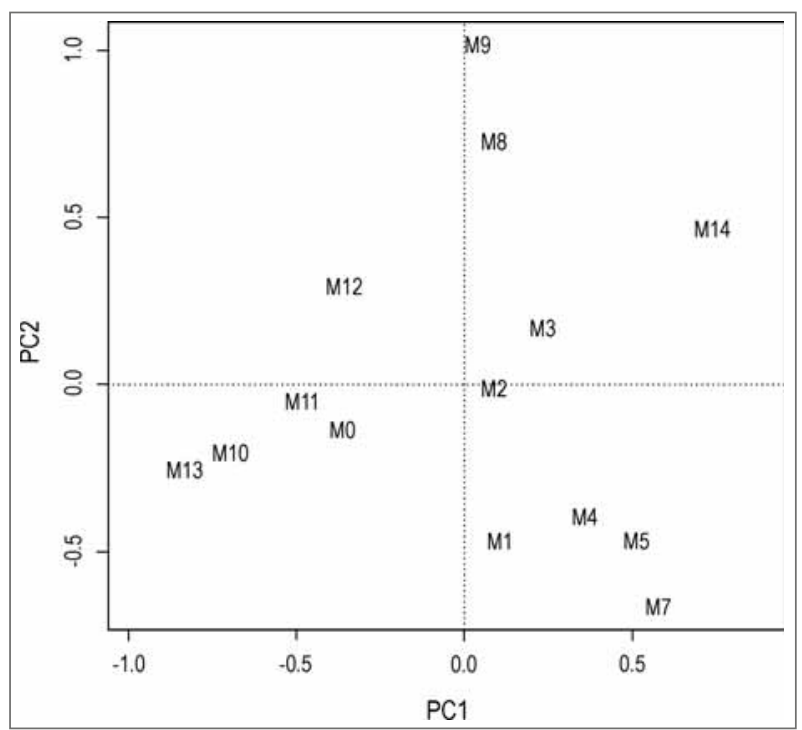

Obr. 3: Podobnosti vzorků na základě euklidovských vzdáleností mezi sebou.

Fig. 3: The similarity of samples based on the Euclidean distance among individual samples. 

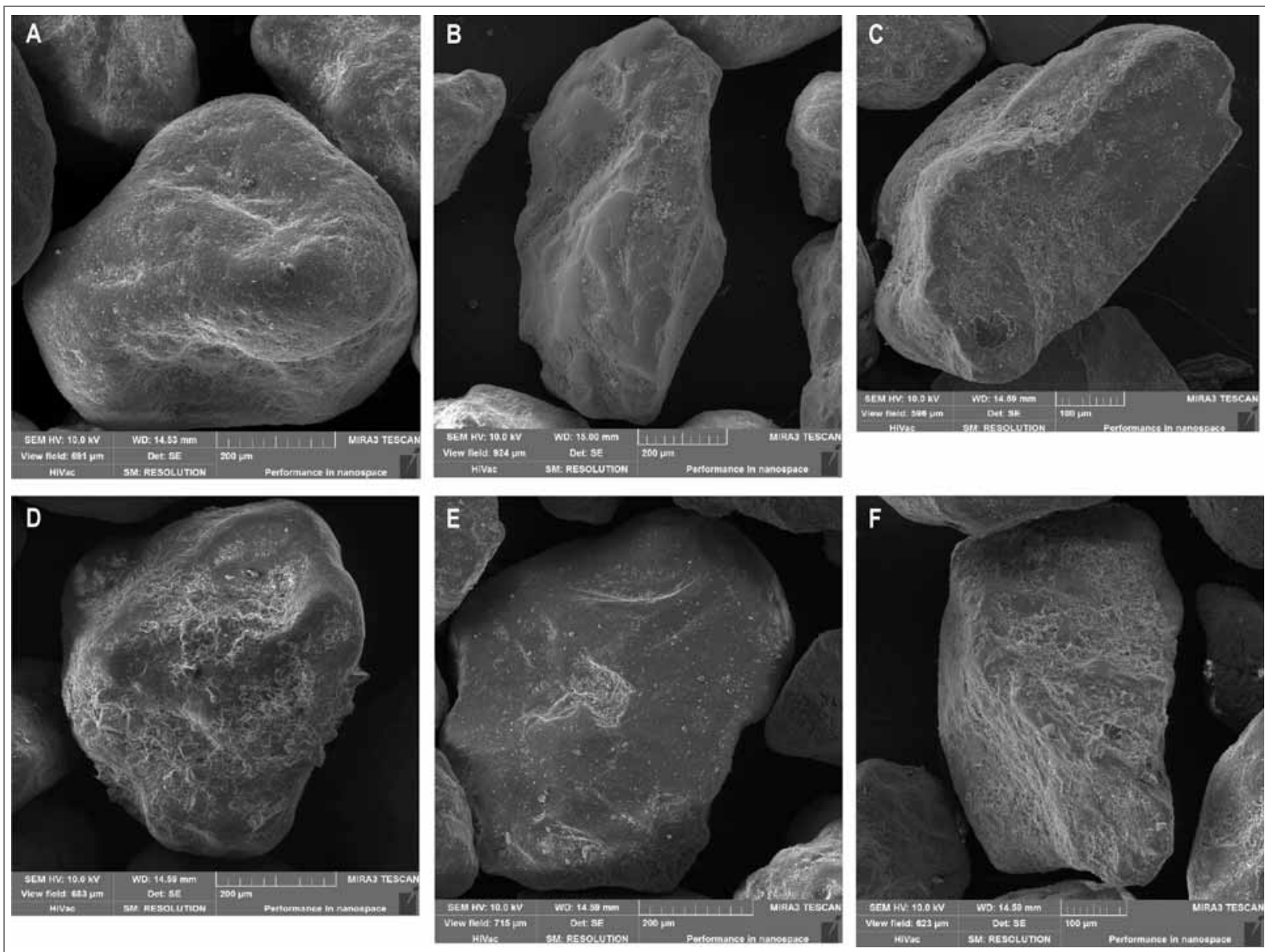

Obr. 4: A - Vzorek M1, tečkování a ohlazené V - jamky, obloukové stupně a přilnavé částice; B - vzorek M1, ohlazený povrch, rovná brázda, přilnavé částice a křemičité skrývky; C - detail křemenného zrna u vzorku M1, rovné stupně, přilnavé částice, křemičité globule a skrývky, lasturnatý lom a tečkování; D - vzorek M2, velmi výrazné křemičité skrývky až nárůsty krystalů, tečkování; E - vzorek M2, vyhlazený povrch s lasturnatým lomem, obloukovými stupni a přilnavými částicemi; F - Vzorek M2, výrazné křemičité skrývky a globule (autor Králová).

Fig. 4: A - Sample M1, pitting and smoothed V-shapedpits, arcuate steps and adhering particles; B - Sample M1, smoothed surface, straight grooves, adhering particles and silica capping; C - Sample M1, detail of the quartz grain, straight steps, adhering particles, silica globules and capping, conchoidal fracture and pitting; D - Sample M2, very significant silica capping up to quartz crystal overgrowths, pitting; E - Sample M2, smoothed surface with conchoidal fracture, arcuate steps and adhering particles; F - Sample M2, significant silica capping and globules (author Králová).

Složením se jedná o dále neurčovanou formu $\mathrm{SiO}_{2}$, tvořící na zrnech povlaky.

\section{Diskuze}

Pozorováním a porovnáváním zrn ve vzorcích se zjistilo, že prakticky ve všech vzorcích převažovala zrna matná a pololesklá nad lesklými. Lesklá zrna byla většinou ta rozlomená s puklinovými plochami a lasturnatým lomem. Matnost zrn způsobilo otukání a vznik impaktních struktur (např. Lisá 2004). Zaoblením se zrna jevila spíše jako poloostrohranná, polooválná a oválná. Oválná zrna měla u některých vzorků tvar spíše pravidelné kuličky (M2, M4, M5) a u některých spíše tvar protažený (M1, M7).

Další patrnou mikrotexturou u zrn byly křemičité povlaky, ty souvisí se sedimentací ve stojatém vodním prostředí (např. Baron et al. 2011), ale jsou pozorované i na eolických písečných zrnech (Le Ribault 2003).

Srovnáním jednotlivých vzorků z Mikulčic mezi sebou se zjistilo, že u všech vzorků je minimální zastou- pení ostrohranných zrn a dokonale oválných zrn, která u některých vzorků zcela chybí. U všech vzorků je největší zastoupení oválných a polooválných zrn. Tento jev je typický pro eolické sedimenty (např. Kř́ižová et al. 2011; Krinsley - Trusty 1985). U většiny vzorků převládá nízký a střední reliéf, což rovněž svědčí pro eolický transport (např. Kř́ržová et al. 2011; Baron et al. 2011).

Vzorky M0 a M1 mají nejnižší zastoupení zrn s nízkým reliéfem a nejvyšší počet zrn s vysokým reliéfem (obr. 7A, B, C). Těmito znaky by spíše odpovídaly fluviálním sedimentům (Křížová et al. 2011; Zaghloul et al. 2009). Zároveň mají tyto vzorky ale poměrně vysoké zastoupení brázd i stupňù, čímž by odpovídaly spíše eolickým sedimentům (např. Kř́íová et al. 2011; Baron et al. 2011).

Největší množství zrn s nízkým reliéfem mají vzorky M5 a M7, které mají zároveň i nejméně zrn s vysokým reliéfem (obr. $8 \mathrm{~B}, \mathrm{C}, \mathrm{D}$ ). Podobnost těchto vzorků byla pozorována již stereomikroskopem. Mají ze zkoumaných vzorků nejvíce mikrotextur inklinujících k eolickým 

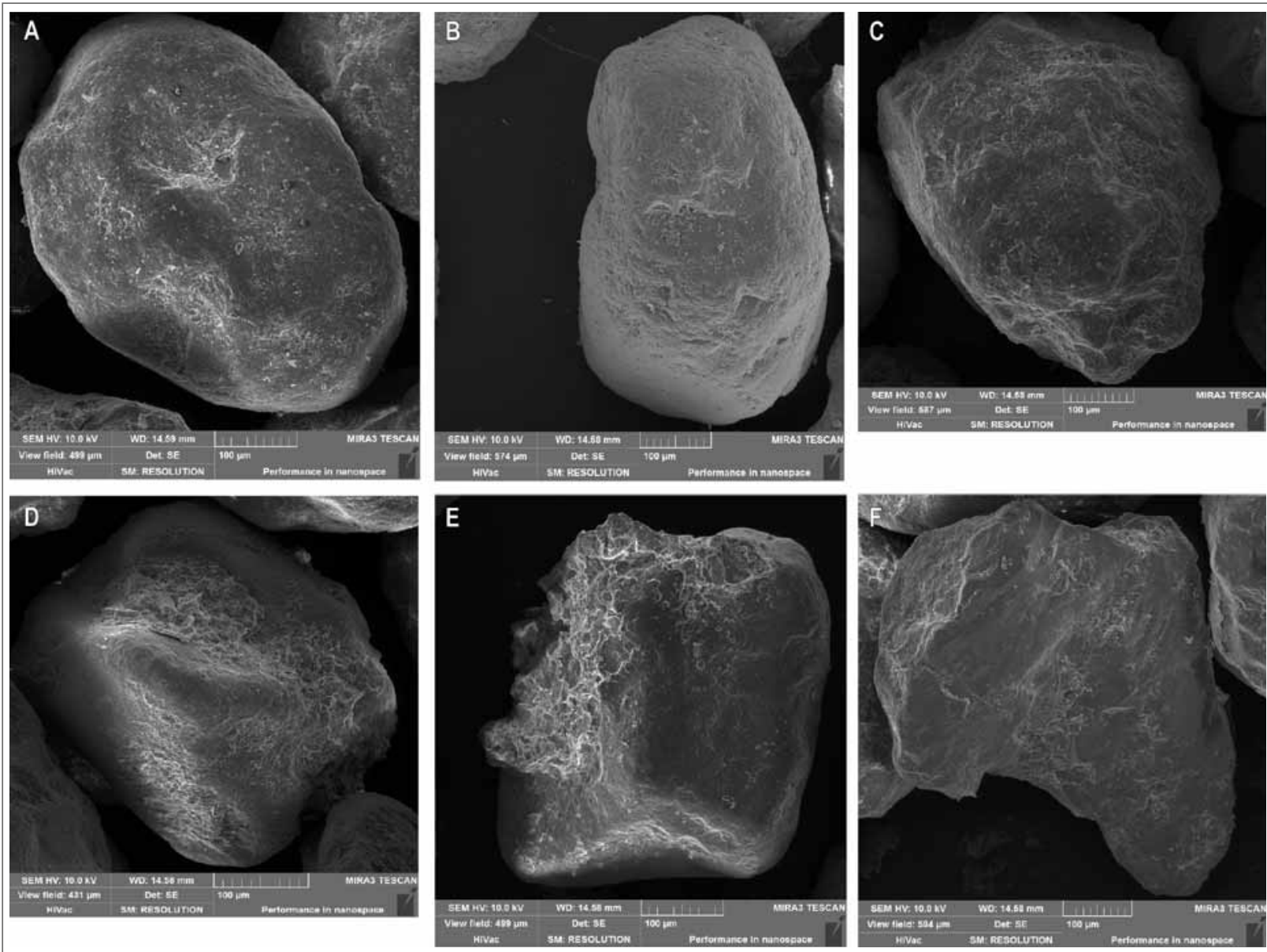

Obr. 5: A - vzorek M2, oválné zrno, tečkování, V - jamky, přilnavé částice, křemičité skrývky; B - vzorek M3, oválné zrno, výrazné $\mathrm{V}$ - jamky a tečkování, přilnavé částice a křemičité povlaky; C - vzorek M3, poloostrohranné zrno, rovné a obloukové stupně,mísovité jamky, přilnavé částice, křemičité globule a skrývky; D - vzorek M4, oválné zrno s výraznými křemičitými skrývkami, povlaky a tečkováním; E - vzorek M4, oválné zrno s výraznými křemičitými skrývkami, povlaky, mísovitými jamkami a tečkováním; F - vzorek M4, rozlomené ostrohranné zrno, abraze hran, lasturnatý lom, přilnavé částice, křemičité skrývky (autor Králová).

Fig. 5: A - Sample M2, rounded outline, pitting, V -shaped pits, adhering particles, silica capping; B - Sample M3, rounded outline, significant $\mathrm{V}$ - shaped pits and pitting, adhering particles and silica pellicle; $\mathrm{C}$ - Sample M3, subangular outline, straight and arcuate steps, dish-shaped breakage concavities, adhering particles, silica globules and capping; D - Sample M4, rounded outline with a significant silica capping, pellicle and pitting; E - Sample M4, rounded outline with the significant silica capping, pellicle, dish-shapped breakage concavities and pitting; F - Sample M4, broken high relief grain, edge abrasion, conchoidal fracture, adhering particles, silica capping (author Králová).

sedimentům. Křemičité nárůsty u těchto vzorků nejsou až tak výrazné v porovnání s ostatními. U vzorku M7 lze ojediněle pozorovat rozpraskání povlaků, které může být znakem pro zvětrávání sedimentu.

Nejvíce zastoupenými mikrotexturami jsou u vzorků M0 - M7 křemičité skrývky, V - jamky a tečkování (obr. 4, $5,6)$. Křemičité skrývky jsou mikrotexturou vznikající ve vodním prostředí o nízké kinetické energii (Kř́ízová et al. 2011). Nacházíme se v oblasti dolního toku Moravy a lze tedy předpokládat nižší energii toku, případně až možnou stagnaci v pozdním pleistocénu (Kadlec et al. 2011). Celkově je u všech vzorků velké zastoupení nárůstových křemičitých mikrotextur.

Použijeme-li ke srovnání vzorky z moravských lokalit, zjistíme následující. Vzorek M0 je nejblíže vzorkům M11, M12 a M13 (obr. 9), které odpovídají střednímu toku řek. Tento vzorek tedy spís inklinuje k fluviálním sedimentům. Jedná se o vzorek, který je nejvíce odlišný od vzorků z Mikulčic. Vzorek M1 (obr. 4A, B, C) je nejblíže vzorku M8 (obr. 8E), který odpovídá eolickým, eolickofluviálním a lakustrinním sedimentům. Vzorek M2 (obr. 4D, E, F) se rovněž nejvíce podobá vzorkům M8 a M12, tedy eolickým, eolickofluviálním a lakustrinním sedimentům. Vzorek M3 (obr. 5B, C) se nejvíce podobá vzorku M8 a M9. Stejně tak i vzorek M4 (obr. 5D, E, F) a M5 jsou nejvíce podobné vzorku M8 (obr. 8E). Vzorek M7 (obr. 6A, B) je rovněž podobný vzorku M8 a nejvíce ze všech vzorků z Mikulčic vzorku M14, tedy eolickému pouštnímu písku (obr. 6C, D).

$\mathrm{V}$ - jamky jsou mikrotexturou typickou pro eolické sedimenty. Mohou se vyskytovat i u fluviálních sedimentů, $\mathrm{v}$ prrípadě vysoké energie toku. V - jamky i jiné impaktní struktury u fluviálních sedimentů pak bývají výrazně větší a hlubší, což není prrípad námi studovaných vzorků. Tečkování je mikrotexturou typickou pro eolické sedimenty (Lisá 2004). 
Mezi dalšími mikrotexturami převládají rovné brázdy, přilnavé částice, mísovité jamky, klikaté hřbítky, křemičité globule a povlaky a obloukové stupně. Jedná se o mikrotextury vyskytující se u eolických sedimentů (Křížová et al. 2011).

Už i při malé délce transportu vznikají na zrnech impaktní struktury. Ke vzniku dun v údolní nivě Dyje i Moravy dochází vyvátím z podložních svrchnopleistocenních fluviálních štěrků (Nehyba - Havlíček 2001; Havlíček 2006). Jejich sedimentace, $s$ různě dlouhými hiáty pokračovala až do spodního a středního holocénu. Ukládaly se vždy jen na povrchu fluviálních písčitých štěrků, ne na povodňových hlínách (Havlíček 2006). Při povodních docházelo i $\mathrm{k}$ částečnému či úplnému rozplavení navátých písků a ukládaly se povodňové hlíny (Adamová - Havlíček 2002). Podle Nehyby - Havlíčka (2001) byly duny částečně připoutané (adheze) a jejich migrace byla málo výrazná. Tento jev byl způsoben periodickým kolísáním hladiny podzemní vody. Tito autoři uvádí průměrnou velikost zrn 0,3-0,7 mm, kdy již dochází k pohybu částic většinou povrchovým krípem, přičemž nejsnadněji se při větrném proudění pohybují saltací písečná zrna o průměru $0,1-0,3 \mathrm{~mm}$. Costa et al. (2013) srovnávají kř̀emenná zrna opracovávaná $\mathrm{v}$ experimentálním tunelu s eolickými zrny křemene z pobřežní duny. Přicházejí na to, že i poměrně malá vzdálenost transportu $v$ poměrně malém časovém úseku, zanechává na zrnech výrazné mikrotextury. Křemenná zrna z portugalského pobřeží vykazují typické mikrotexturní znaky, jako silné zaoblení, zakulacené hrany, silné rozpouštění (naleptání), nárazové deprese a prrítomnost četných přilnavých částic.

$\mathrm{V}$ roce 2012 byla provedena srovnávací studie povrchu křemenných zrn na lokalitách pouští Gobi a Rub'al-Khali (Šušolová et al. 2013). Zrna z pouště Rub'al-Khali jsou matná, případně pololesklá a převládají polooválná až oválná zrna. Srovnáme li vzorky z Mikulčické duny se vzorky typické duny z pouště Rub'al- Khali, nalezneme četné rozdíly. U vzorků z pouště Rub'al-Khali se prakticky vůbec nevyskytují křemičité nárůsty, zato převládají $\mathrm{V}$ jamky, tečkování, rovné brázdy a mísovité jamky.

\section{Závěr}

Odebrané vzorky písků z geneticky odlišných prostředí lokality Mikulčice byly podrobeny studiu nejprve pod stereomikroskopem a poté autoemisním elektronovým mikroskopem MIRA3. Na zrnech lze pozorovat ohlazené $\mathrm{V}$ - jamky a impaktní struktury, u některých až hladký povrch. Lze pozorovat, že zrna prošla procesem, díky kterému se na nich objevily impaktní struktury, došlo k jejich rozlomení, vznikl lasturnatý lom či abraze hran atd., a poté byla zrna potažena křemičitými povlaky, skrývkami či u nich došlo k nárůstům krystalů, vyplňujících právě impaktní nerovnosti zrna. Na základě výsledků výzkumu je patrné, že vývoj sedimentů v rámci Slovanského Hradiště v Mikulčicích probíhal ve velmi podobném sedimentárním prostředí. V tomto prostředí hrál významnou roli eolický transport a důležitý byl rovněž i fluviální transport o nižší kinetické energii. Psamitické sedimenty v této oblasti prošly vývojem v několika sedimentárních prostředích a nelze 

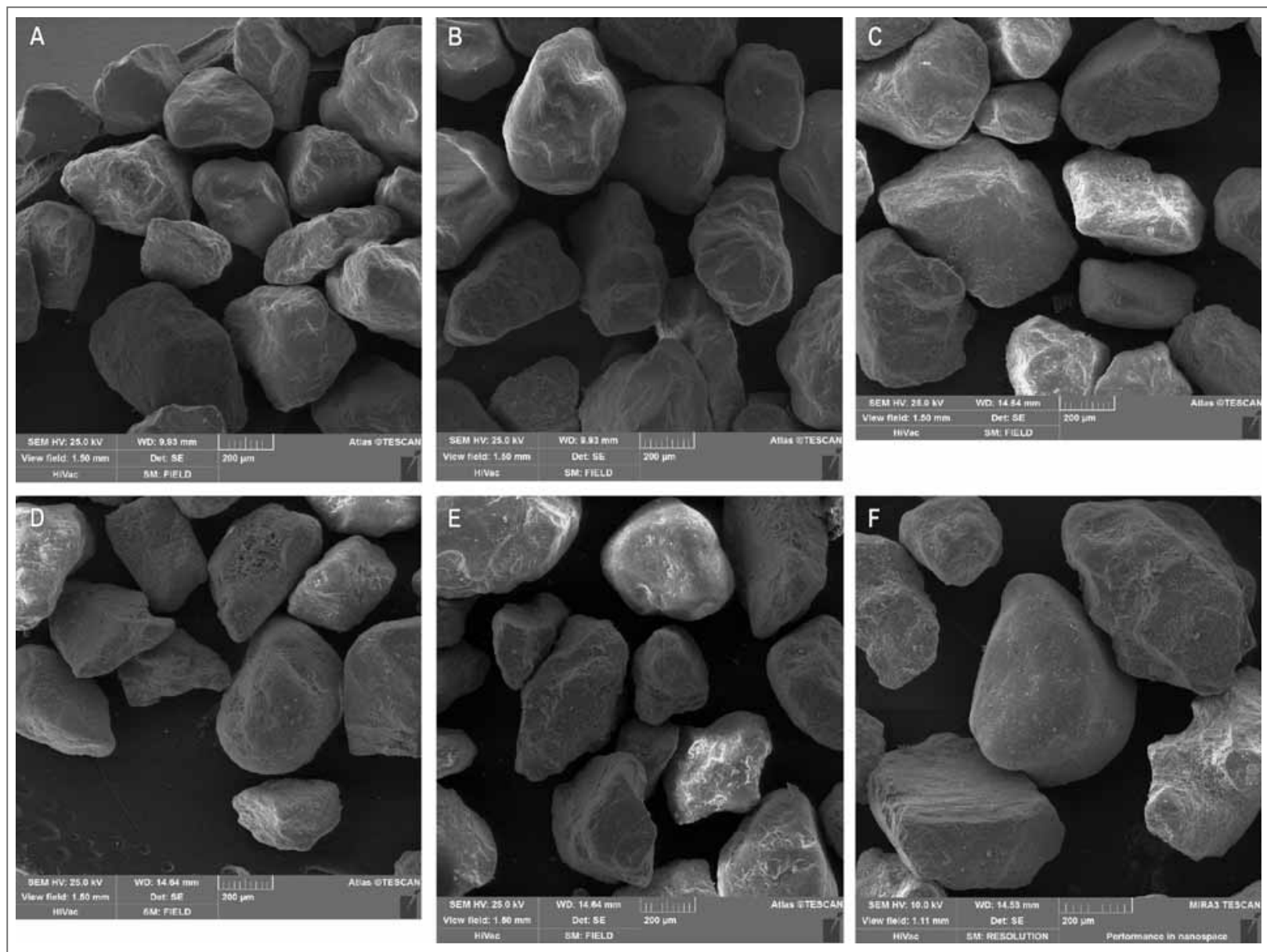

Obr. 7: Detail křemenných zrn u vzorků: A, B/ M0 - Trapíkov; C/ M1 - Trapíkov; D/ M2 - Hradisko; E/ M3 - Hradisko; F/ M4 Hradisko (autor Králová).

Fig. 7: Detail of the quartz grains from the samples: A, B/ M0 - Trapíkov; C/ M1 - Trapíkov; D/ M2 - Hradisko; E/ M3 - Hradisko; F/ M4 - Hradisko (author Králová).

je z hlediska původu přiřazovat k sedimentům jednoznačně geneticky daným.

\section{Poděkování}

Chtěli bychom poděkovat firmě Tescan za umožnění výzkumu na autoemisním elektronovém mikroskopu a Karlu Maroszovi za určení zrnitosti pipetovací metodou. Poděkování patři i recenzentům za podnětné připomínky a především finanční podpoře projektu Moravského zemského muzea. Předložená práce vznikla za finanční podpory Ministerstva kultury v rámci institucionálního financování na dlouhodobýkoncepční rozvoj výzkumné organizace Moravskézemské muzeum (DKRVO, MK000094862). 

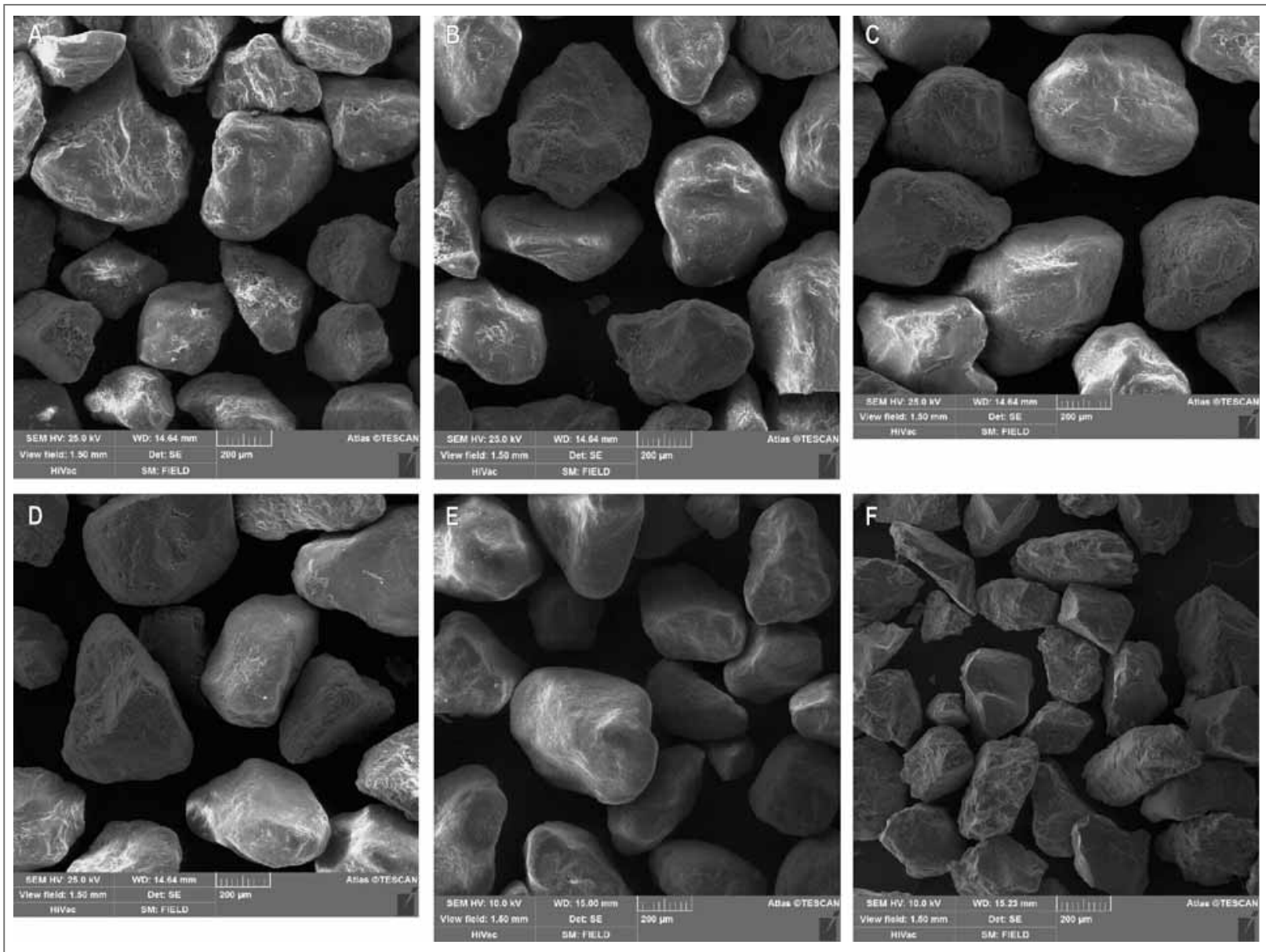

Obr. 8: Detail křemenných zrn u vzorků:
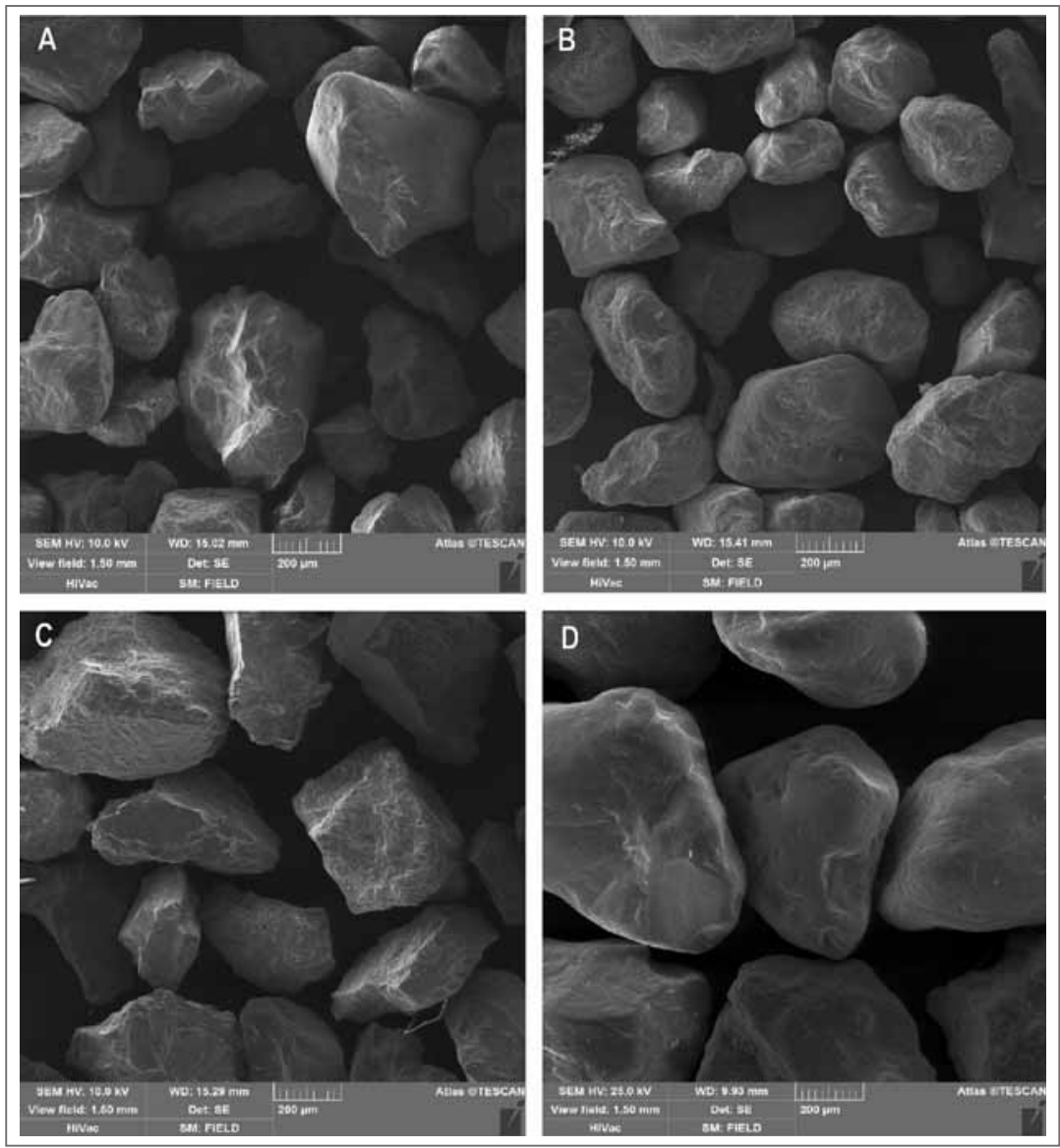

A/M4 - Hradisko; B/ M5 - Hradisko; C, D/ M7 - Hradisko; E/ M8 - Osypané břehy A; F/ M10 - Litenčice (autor Králová).

Fig. 8: Detail of the quartz grains from the samples: A/ M4 - Hradisko; B/ M5 Hradisko; C, D/ M7 - Hradisko; E/ M8 - Osypané břehy A; F/ M10 - Litenčice (author Králová).

Obr. 9: Detail křemenných zrn u vzorků: A/ M11 - Olšava; B/ M12 - Morava; C/ M13 - Jevišovka; D/ M14 - Rub 'al-Khali (autor Králová).

Fig. 9: Detail of the quartz grains from the samples: A/ M11 - Olšava; B/ M12 - Morava; C/ M13 - Jevišovka; D/ M14 Rub'al-Khali(author Králová). 


\section{Literatura}

Adamová, M. - Havlíček, P. (2002): Geochemický výzkum subfosilní polygenetické pseudočernozemě a navátých písků při soutoku Dyje s Moravou („Barvínkův hrúd“). - Zprávy o geologických výzkumech v roce 2001, 117-118.

Atkinson, O. A. C. - Thomas, D. S. G. - Goudie, A. S. - Bailey, R. M. (2011): Late Quaternary chronology of major dune ridge development in the northeast Rub`al-Khali, United Arab Emirates. - Quaternary Research, 76, 93-105.

Baron, J. C. - Grab, S. W. - Kuman, K. (2011): Surface texture analysis of southern Tuli Basin sediments: Implications for Limpopo Valley geoarchaeological contexts. - Journal of African Earth Sciences, 59, 384-394.

Costa, P. J. M. - Andrade, C. - Mahaney, W. C. - Marques da Silva, F. - Freire, P. - Freitas, M. C. - Janardo, C. - Oliveira, M. A. - Silva, T. - Lopes,V. (2013): Aeolian Microtextures in Silica Spheres Induced in Wind Tunnel Experiment: Comparison with Aeolian Quartz. - Geomorphology, 180-181, 120-129.

Havlíček, P. (2006): Př́rodní park Niva Dyje (jižní část): geologie kvartérních sedimentů a vývoj údolní nivy. - Zprávy o geologických výzkumech v roce 2005, 71-73.

Havlíček, P. - Peška, J. (1992): K osídlení dun v soutokové oblasti Moravy s Dyjí. - Jižní Morava 28, sv. 31, 239-249.

Havlíček, P. - Zeman, A. (1986): Kvartérní sedimenty moravské části vídeňské pánve. - Sborník geologických věd, Antropozoikum, 17, 9-41.

Chlupáć, I. - Brzobohatý, R. - Kovanda, J. - Stráník, Z. (2002): Geologická minulost České republiky. - 436 s.Academia. Praha. Jandák, J. a kol. (2009): Cvičení z půdoznalství. -Ediční středisko Mendelova univerzita v Brně. Brno.

Kadlec, J. a kol. (2011): Late Glacial lacustrine and fluvial processes in the Lower Moravian Basin (Czech Republic). - Poster z konference Reconciling modern and Quaternary rates of landscape evolution, 21. - 27. 7. 2011, Bern. (INQUA 2011: session on Quaternary Landscape Evolution)

Krinsley, D. H. - Trusty, P. (1985):Environmental interpretation of quartz grain surface textures. - In: Zuffo, G. G. (ed.), Provences of Arenites. D. Reidel Publishing Co., Boston, 213-229.

Křížová, L. - Kř́žek, M. - Lisá, L. (2011): Význam povrchové analýzy křemenných zrn pro studium geneze nezpevněných sedimentů. - Geografie, 116, 1, 59-78.

Le Ribault, L. (2003): LLR et le G5: Baladesurun grain de sable. - Dostupné na: http://www.loic-le-ribault.ch/exo_balademicroscopique_p03.php, 10.8.2016

Lisá, L. (2004): Exoscopy of Moravian eolian sediments. - Bulletin of Geosciences, 79, 3, 177-182.

Nehyba, S. - Havlíček, P. (2001): Granulometrie kvartérních sedimentů v soutokové oblasti Moravy s Dyjí. - Zprávy o geologických výzkumech v roce 2000, 1, $84-87$.

Šušolová, J. - Dundek, P. - Hadacz, R. - Králová, V. - Kynický, J. (2013): Srovnávací studie povrchu křemenných zrn na lokalitách pouští Gobi a Rub'al-Khali. - In: Juřička, D. - Jánošíková, L. - Cihlářová, H. - Brtnický, M. - Kynický, J. (2013): Scientific research of Mongolia and Central Asia. 1.vyd., 28-37. Brno.

Zaghloul, M. N. -Reddad, H. -Critelli, S. (2009): Source-area controls on the composition of beach and fluvialsands on the southern side of the Gibraltar Strait and Western Alboran Sea (Flysch Basin, Internal and External, Domains, Northern Rif Chain). -Journal of African Earth Sciences, 55, 36-46.

ČNI (1990): ČSN 72 1001, Pomenovanie a opis hornín v inžinierskej geológii. - Český normalizační institut. Praha.

ČNI (1988): ČSN 73 1001, Zakládání staveb. Základová půda pod plošnými základy. - Český normalizační institut. Praha.

Munsell Color (2000): Munsell Soil Color Charts. Revised washable edition, 10 pp + charts, Gretag Macbeth, New Windsor, NY. http://www.zemepis-vorlicek.estranky.cz/file/39/cr-vodstvo.jpg, 10. 8. 2016. 